\title{
NEW MISCELLANEOUS CHALCID-FLIES FROM NORTH AMERICA.
}

\author{
By A. A. Girault. \\ Bureau of Entomology, Washington, D. C. \\ Pseudiglyphomyia marilandica sp. nov.
}

Female: Length, $1.00 \mathrm{~mm}$. Very similar to nigrivariegata Girault but somewhat smaller and differing also in the following particulars: The general color is orange; the face of prothorax has a black stripe across it; cephalic margin of scutum rather broadly black; the parapsidal furrows and the suture between scutum and scutellum are more noticeably black; also black thus-there is a moderately large round spot in the center of the scutellum; the spot on the axillæ is more distinct; the cephalic margin of the propodeum narrowly out a little laterad of the spiracle and an oblique stripe from base between meson and spiracle, extending well toward apex; and seven narrow cross-stripes on dorsal abdomen from base to apex, the first broadly interrupted at the meson. Prothorax lemon yellow. Tegulæ dusky, also the antennæ, the scape paler except on dorsal edge and toward the apex. Mandibles 6-dentate. Funicle joints subequal, each twice longer than wide and longer than the pedicel; club 1 nearly as long as funicle 1, longest, 3 with a distinct terminal spicule. The propodeum is as in nigrivariegata but there is no very narrow lateral carina directly from the minute round spiracle which is not very close to the cephalic margin. Types compared.

One female, open woods, Glenndale, Md. (September 28, 1916).

Type: Catalogue No. 20622, U. S. National Museum, the female on a tag, the head and the hind tibiæ on a slide.

\section{Euplectrus platypenæ Howard.}

Reared from a larva on grass, Barbados, B. W. I., January, 1915 (F. Watts).

Gonatocerus illinoiensis sp. nov.

Female: Similar to the description of juvator Perkins but the legs are yellow except all tibiæ and tarsi besides the prothorax, lateral and caudal margins of scutum and the parapsides except apex 
(cephalad). Fore wings subhyaline. Middle and hind coxæ black. A most beautiful species when alive.

One female, window of a laundry, Coulterville, Ill., June 10, 1911.

Type: Catalogue No. 20631, U. S. National Museum, the female on a slide.

Neomphaloides cincinnatus sp. nov.

Female: Length, $1.20 \mathrm{~mm}$. Slender, the stylus a little shorter than the ovipositor and a third of the abdomen's length.

Dark metallic blue, the wings hyaline, the venation and scape pale, the tarsi, knees, cephalic and middle tibiæ and the caudal legs except the coxæ golden yellow. Abdomen above and below with a large peltate spot of golden yellow at base (base and lateral margin narrowly concolorous, the yellow reaching to apex of basal third) and with over the basal half of the stylate part golden yellow. Pedicel but somewhat longer than wide, about half the length of funicle 1, the latter slightly longest, thrice or more longer than wide, the club joints twice longer than wide, the third with a distinct but not elongate terminal spine. Mandible tridentate, the third tooth obliquely truncate. Stylus hairy. Punctures along lateral margin of scutum very delicate, obscure. Sculpture usual but the propodeum rather coarsely scaly, with a narrow median carina and a similar, straight lateral one, the spiracle minute, round, halfway between middle and cephalic margin.

One female, woods, Glenndale, Md., September 9, 1916.

Type: Catalogue No. 20472, U. S. National Museum, the female on a tag, the head on a slide.

A second female, same place, some days later.

\section{Dibrachys clisiocampæ (Fitch).}

Four females reared from the larvæ of Phthorimaea operculella, Pasadena, Calif. (J. E. Graf).

Polynema bifasciatipenne (Girault) varium var. nov.

Female: Differing from the typical form in being light yellowish brown, including the legs; distal stripe of fore wing nearly as long (or even longer) as the middle one and subrectangular, its apical margin flatly convexed, its basal nearly straight. Ovipositor black except at base, more extruded (for a length equal to a third 
of that of the abdomen's body or nearly as long as the slenderer petiole). And the hind wings are wholly hyaline.

The male has a fuscous band across the abdomen a little before apex.

One male, three females described in detail in Journ. New York Ent. Soc., December, 1910, pp. 254-258. Locality, Fredonia, Kans.; eggs of Ecanthus.

Types: Catalogue No. 20599, U. S. National Museum, one male, three females on tags.

Anaphoidea conotracheli (Girault).

From eggs of Craponius incequalis, West Virginia (F. E. Brooks).

Eutelus betulæ sp. nov.

Female: Length, $1.00 \mathrm{~mm}$. Dark metallic green, the wings hyaline, the scape, most of the pedicel, venation, cephalic tibiæ, tips of other tibiæ and the tarsi, yellowish brown. Body finely scaly punctate, the propodeum and abdomen scaly, the former tricarinate but the median carina weak, subobsolete. Parapsidal furrows incomplete. Propodeal spiracle minute, rounded, its own diameter from the cephalic margin. No spiracular sulcus. Abdomen conic-ovate, a little longer than the rest of the body, depressed or sunken above, its second segment occupying a fourth of the surface. Lateral ocelli far distant from the eyes. Clypeus small, not advanced, sharply incised at the meson, thus bidentate, its teeth obtuse. Mandibles 3- and 4-dentate. Antennæ inserted near the clypeus, a little below the ventral ends of the eyes, 13jointed with three ring-joints, the third of the latter largest; funicle joints subquadrate, subequal, somewhat shorter than the pedicel. Stigmal vein a half shorter than the marginal, somewhat shorter than the postmarginal.

The male is similar but the abdomen is much shorter, depressed and obtuse at apex.

From two pairs reared from "Cecidomyiia betuloe, Albany, N. Y., June 10, 1887 (J. A. Lintner)."

Types: Catalogue No. 20789, U. S. National Museum, two pairs on tags, appendages on a slide. 
Eutelus salicis sp. nov.

Female: Length, $2.15 \mathrm{~mm}$. Like the preceding but much larger, the pedicel is entirely reddish yellow and larger (also the first two ring-joints; funicle 1 is about twice longer than wide), the femora reddish yellow; the clypeus is not incised but broadly sinuate or concaved; the abdomen is longer and stylate, not sunken, the antennæ inserted barely below the ventral ends of the eyes; the propodeum is about as in Habrocytus onerati and the marginal vein is somewhat larger. Differs from $H$. onerati (Fitch) mostly in that the flagellum is black, the antennæ with three ring-joints and somewhat lower on the face.

From three females reared from a conical Cecidomyid gall on Salix longifolia, Melrose, Mass., January 20, 1882 (U. S. Department Agriculture).

Types: Catalogue No. 20788, U. S. National Museum, the three females, minutien-mounted and a slide bearing caudal tibiæ and a head.

\section{Achrysocharella pulchrella sp. nov.}

Female: Length, $1.00 \mathrm{~mm}$. Bright orange yellow, the abdomen somewhat paler, the wings hyaline, the body marked with dark metallic blue as follows: Pronotum, cephalic half of scutum, a dot on each side, center of occiput, a tolerably broad stripe across the base of the abdomen, followed immediately by a narrow crossstripe and then at intervals equal to the basal stripe (except in the first instance) by four sometimes thicker cross-stripes, the last one of which is at base of distal third. Legs, scape and pedicel, white, the funicle and club dusky. Tip of ovipositor valves black. Head and thorax very finely punctate, the propodeum and abdomen scaly. Propodeum plane, with a median carina and a oblique carina just laterad of the rounded spiracle. Scutellum with a seta on each side of the middle, somewhat flattened. Postmarginal vein shorter than the stigmal. Terminal spine of the club as long as its joint; pedicel, funicles 1-2 and club 1 subequal, twice longer than wide; club 2 somewhat shorter, 3 still shorter. Club narrowing distad. Mandibles with two acute outer teeth and a third inner which is rather broadly truncate at apex and there with minute teeth. Parapsidal furrows barely indicated cephalad. Habitus of the Australia grandis. 
From one female in the U. S. National Museum Collection from the District of Columbia.

Type: Catalogue No. 20438, U. S. National Museum, the female on a card, the head on a slide.

\section{Atoposomoidea ogimæ Howard. Genotype.}

Same as Diaulinopsis but postmarginal abbreviated. Head normal.

\section{Grotiusomyia flavicornis sp. nov.}

Female: Length, $1.20 \mathrm{~mm}$. Aeneus black, the wings hyaline, the legs (except the coxæ and femora) and the antennæ, straw yellow. Pedicel dusky. Head and thorax finely scaly punctate, the abdomen scaly except segment 2 which is glabrous (except at apex). Postscutellum and propodeum subglabrous, the latter with a strong median carina and a curved smooth sulcus in the site of the lateral carina, the mesal margin of which is an obtuse carina; spiracle elliptical, of moderate size, cephalad. Parapsidal furrows complete, fine like lines. Pronotum transverse-quadrate, over half the length of the scutum. Segment 2 of abdomen much the largest, occupying a third of the surface, its caudal margin straight. Axillæ considerably advanced. Marginal vein as long as the submarginal, over twice the length of the long stigmal, the latter distinctly shorter than the postmarginal. Mandibles $6=$ and $7=$ dentate. Club $2=$ jointed, nippleless, the joints about equal in length, 1 a little wider than long. Pedicel somewhat longer than wide, the funicle joints shortening and widening, 1 slightly shorter than the pedicel, the others wider than long. Antennæ clavate. Femora usually yellow except the caudal ones.

From six females reared from an oak pyralid, Washington, D. C. Types: Catalogue No. 20695, U. S. National Museum, the females on tags (1 minutien), a head and four caudal legs on a slide.

\section{Aphidencyrtus aspidioti Girault.}

A pair from Lepidosaphes ulmi, Monmouth, Me., July 22, 1914 (E. H. Siegler). The male bears two ring-like funicle joints and a very long, solid club, the antennæ $5=$ jointed. 
Lamprostatus canadensis sp. nov.

Female: Length, $2.45 \mathrm{~mm}$. Stout. Dark metallic green, the wings hyaline, the venation dusky yellow, the tibix and tarsi reddish brown. Head and thorax densely scaly, the scutellum with a deep, foveate cross-suture before its apex and at base with a short median sulcus and row of small punctures along its lateral margin; propodeum with a median carina (and no others) from which run more or less distinct oblique rugæ; also a lateral carina distad only, the spiracle moderately large, ovate. Petiole wider than long, the second abdominal segment occupying not quite half of the surface, its caudal margin straight but with a short slit at the meson. Antennæ inserted a little below the middle of the face, above the ventral ends of the eyes; clypeus not advanced but at each end with a stout tooth and another in the middle (of its ventral margin); an obtuse ridge from the clypeus to the antennæ along the meson. Parapsidal furrows deep, distinct. Suture between pronotum and scutum distinct. Antennae $13=$ jointed with two ring-joints, the club wider than the funicle but not half its length; funicle 1 a third longer than wide, 6 quadrate, longer than the pedicel. Scape not long. Postmarginal vein longer than the marginal, the stigmal long, a little shorter than the marginal. Abdomen flat above, much keeled beneath, smaller than the thorax. Mandibles 3= and 4=dentate.

Described from one female in the U. S. National Museum from Banff Springs, Alberta, Can. (E. A. Schwarz).

Type: Catalogue No. 20429, U. S. National Museum, the specimens on a tag, the head, caudal legs and a fore wing on a slide.

\section{Miscogaster flora sp. nov.}

Female: Length, $2.10 \mathrm{~mm}$. Like abnormicolor but only the caudal tibiae are purple and the blotch on the fore wing does not form a crescent but is a large, oblique marking from the apex of the stigmal vein, its sharp end caudo-proximad; the clypeus is somewhat more produced. Funicle $5=$ jointed.

From two females, Jacksonville, Fla. (Ashmead).

Types: Catalogue No. 20790 U. S. National Museum, the specimens on tags, a head, fore wing and caudal tibiæ on a slide. 
Miscogaster biguttata sp. nov.

Female: Length, $2.25 \mathrm{~mm}$. Similar to flora but the legs all white, the fore wings bear two small, rounded spots, one at the apex of the stigmal vein, the other, larger and somewhat quadrate, at the base of the marginal vein. In some males, the proximal spot is absent and there is a narrow, yellow cross-stripe at about apex of proximal fourth. Antennæ nearly all yellow.

From five males, one female with flora.

Types: Catalogue No. 20791, U. S. National Museum, the specimens on tags.

\section{Megorismus poloni sp. nov.}

Female: A third smaller than lasiopterce Ashmead and differing from that species notably in having the antennæ wholly concolorous except the bulla; also, as follows: the antennæ are inserted somewhat farther ventrad, on a level with the ventral ends of the eyes; the clypeus is stoutly bidentate at the apical meson instead of unidentate, as in the other species; the propodeum is subglabrous and though tricarinate there is not a cross-carina consisting of three rugæ which converge at the meson from each side. Segment 2 of abdomen occupying nearly a half of the surface; its caudal margin at meson with a short slit. Lateral carina of propodeum failing just before the cephalic margin. Postmarginal vein more or less subequal to the marginal, longer than the slender stigmal. Prothorax distinct. Parapsidal furrows complete, shallow. Scutellum with a shallow cross-suture before the apex. Petiole of abdomen quadrate, reticulate, the abdomen conic-ovate, pointed ventrad, about as long as the thorax. Antennæ 13-jointed with two ring-joints; funicle 1 a little longer than wide, much shorter than the subelongate pedicel; funicles 2-4 subequal to 1,6 quadrate. Scape long and slender. Tibiæ at each end yellowish brown. Mandibles 4-dentate.

Described from four females from Placer County, California, August (U. S. National Museum).

Types: Catalogue No. 20792, U. S. National Museum, the specimens, minutien-mounted and a slide bearing a head and caudal tibiæ.

In the species lasiopterce, segment 2 of the abdomen is shorter than in poloni and its caudal margin is entire. 
Trydymus æneicornis sp. nov.

Female: Half the size of robiniocola Ashmead and differing farther in having the antennæ wholly metallic green and also the legs except knees, tips of tibiæ and tarsi; otherwise the same but the spiracle of the propodeum is smaller and about its own diameter from the cephalic margin. The clypeus at apex is distinctly convexly projected. Valves of ovipositor distinctly shortly extruded. First ring-joint extremely short. Pedicel longer than the subquadrate funicle 1. Otherwise as in the named species.

Described from one female taken from a plum tree in New York State, May 25, 1888.

Type: Catalogue No. 20425, U. S. National Museum, the female on a tag and a slide.

\section{Trydymus gargantua sp. nov.}

Female: Length, $2.30 \mathrm{~mm}$. Like oneicornis but very much larger, a third or more larger than americensis or robinicecola and differing farther as follows: the scape is yellow at extreme base, the pedicel at apex and beneath, the funicle and club all so except above; the legs are golden yellow except the coxæ and the proximal two thirds (less on cephalic femur) of the femur which are metallic; the ovipositor is not at all extruded and the propodeal spiracle is large, oval and at cephalic margin. Pedicel subequal to funicle 1. The same otherwise.

The male is similar but the funicle is 6-jointed, the club 2jointed, funicle 1 shorter.

Described from a pair from Ithaca, N. Y. (Cornell University).

Types: Catalogue No. 20426, U. S. National Museum, the pair on tags, male and female antenna and caudal legs on a slide.

The clypeal projection is somewhat more prominent in this species.

\section{Trydymus poloni sp. nov.}

Female: Like gargantua but the ovipositor is a little extruded, the legs are golden yellow except most of the middle and all of the caudal coxæ, the antennæ so except the scape above at distal two thirds, the pedicel above and the funicle joints too, more or less; the projection of the clypeus is not convex but subtruncate; the fovex along the cephalic margin of the propodeum are minute and 

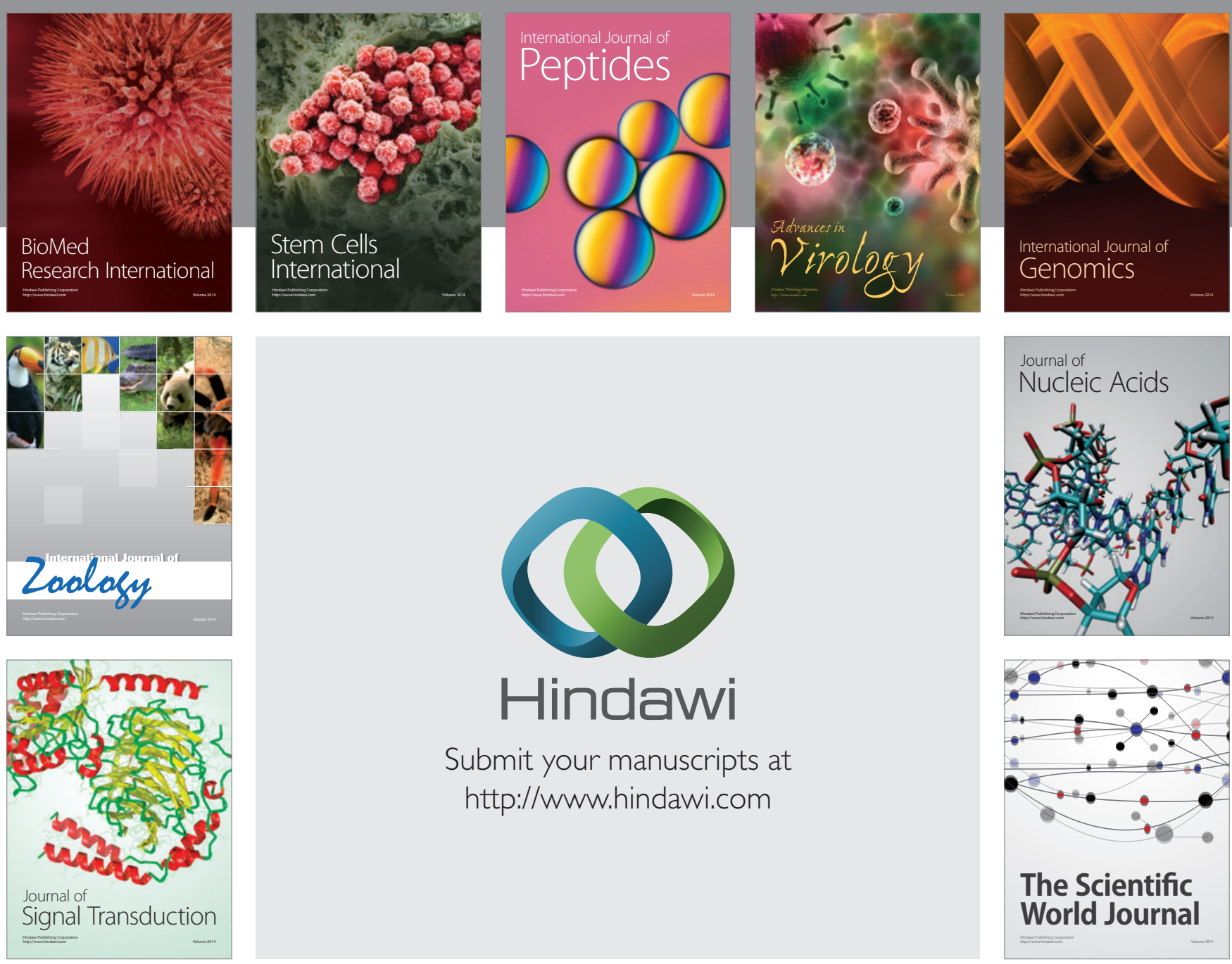

Submit your manuscripts at

http://www.hindawi.com
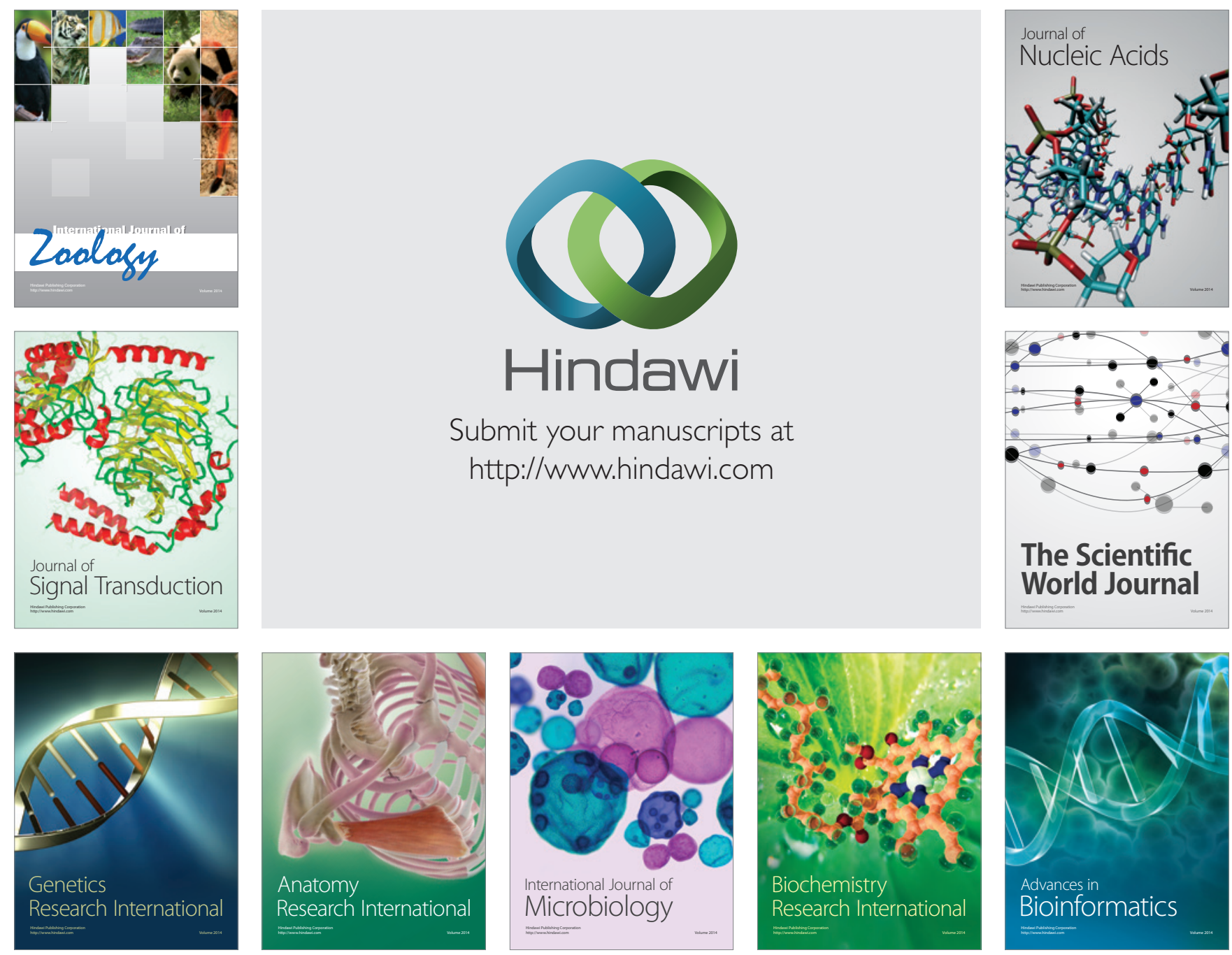

The Scientific World Journal
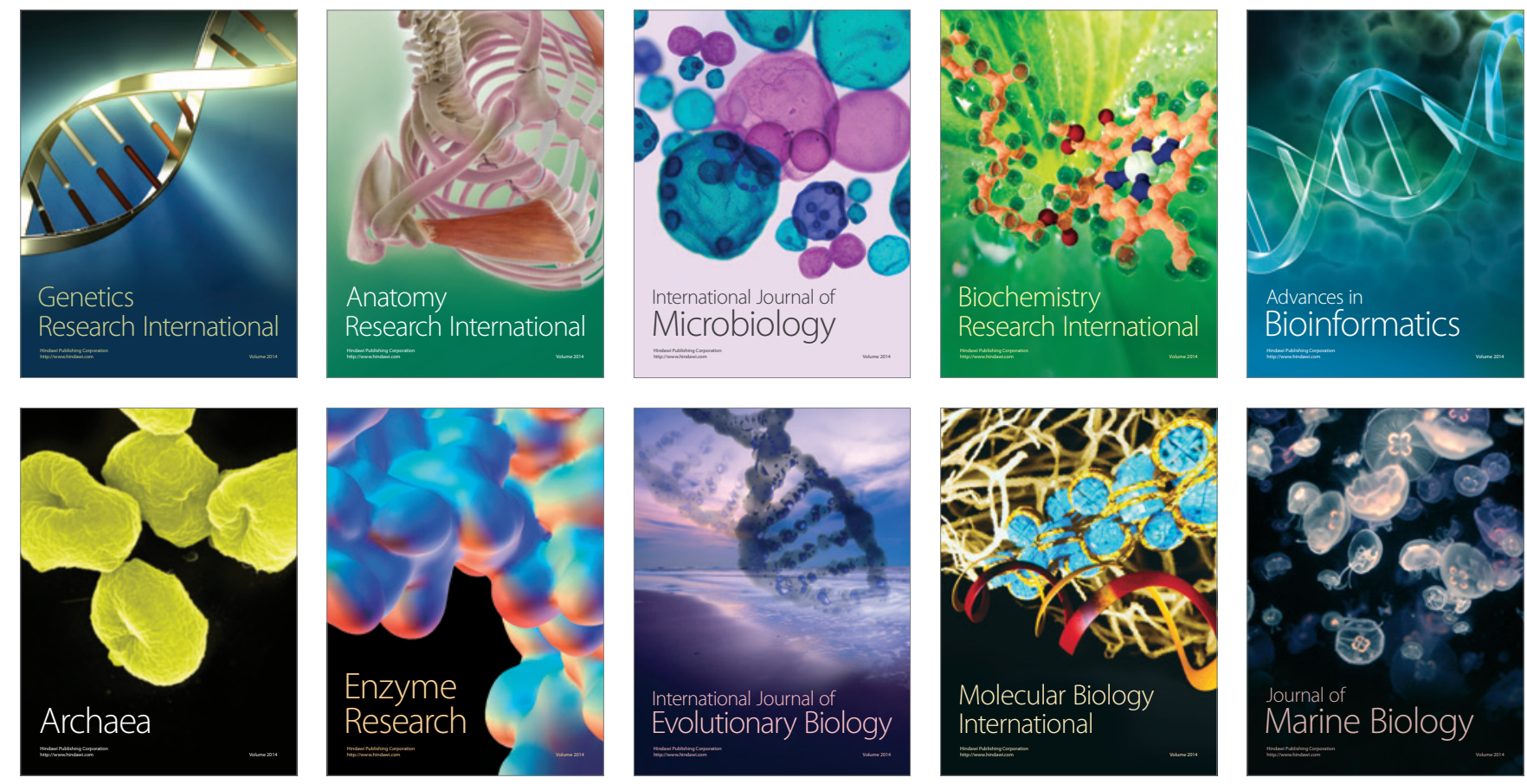